\title{
Skimun á meðgöngu og fósturgreining
}

Alla tíð hafa leikir og lærðir reynt að gera sér grein fyrir líðan barns í móðurkviði, eiginleikum pess, kyni, heilsu og horfum, án tillits til möguleika okkar til að hafa áhrif par á. Í læknisfræði og heilsuvernd okkar tíma leggjum við okkur pó almennt fram um að skima eftir og greina aðeins ástand og sjúkdóma sem hægt er að meðhöndla, fyrirbyggja eða milda. Petta á sannarlega við í mæðravernd, par sem mjög víðtæk skimun er eitt helsta verkfærið.

Leiðin hefur verið löng frá bábiljum um að lögun legs og kviðar á meðgöngu segi til um kyn barnsins til pess að nú er hægt að greina erfðamengi fóstursins í einu litlu blóðsýni úr móðurinni. Hraðinn á peirri leið hefur hins vegar verið eins og veldisvöxtur og engin ástæða er til að ætla að par hægi nokkuð á. Fræðin eru orðin umfangsmikil og fósturgreining og meðgöngusjúkdómar (fetal medicine) hafa frá 2015 verið viðurkennd sem ein af 5 undirsérgreinum fæðinga- og kvensjúkdómalækninga hérlendis.

Skimun á meðgöngu felur í sér fjölmargt. Snemma í pungun er meðgöngulengd ákvörðuð með ómskoðun, en pað er mikilvæg forsenda pess að hægt sé að fylgjast með fósturvexti og eykur öryggi síðar á meðgöngunni. Skimað er eftir gömlum og nýjum sýkingum, blóðleysi, rauðkornamótefnum, frávikum í fósturvexti, háprýstingi og heilsuspillandi lifnaðarháttum auk áhættupátta meðgöngueitrunar, sykursýki, skjaldkirtilssjúkdóma, segahneigðar og geðrænna vandamála. Í ómskoðun við 20 vikna meðgöngu er skimað eftir sköpulagsgöllum og óeðlilega staðsettri fylgju. Pá eru ótaldar viðbótarskimanir og eftirlit í fjölburameðgöngum. Allt ofangreint er að jafnaði boðið hverri barnshafandi konu en einnig mælt með аð hún piggi og er henni að kostnaðarlausu.

Auk pessa eru möguleikar á skimun og greiningu á litningafrávikum og par hefur próunin verið hvað hröðust undanfarið. Mælt er með að barnshafandi konum í mæðravernd séu boðnar upplýsingar um pessa skimunarmöguleika, en ekki beinlínis boðin skimunin sjálf í fyrstu og enn síður mælt með henni, sem er heldur ekki ókeypis.

Hérlendis er í dag skimað með sampættu líkindamati við 11-13 vikna meðgöngulengd eftir premur litningaprístæðum: 21, 18 og 13, sem birtast í heilkennum Downs, Edwards og Patau (í sömu röð). Gefnar eru tölulegar líkur á pessum prístæðum út frá niðurstöðum ómskoðunar og lífefnavísum. Pessi skimun getur að auki vakið grun um og leitt til greiningar á öðrum frávikum, til dæmis prílitnun (triploidy), Turner-heilkenni, ýmsum sköpulagsgöllum og vaxtarseinkun svo eitthvað sé nefnt. Vakni grunur eða séu líkur „auknar“ á litningafrávikum parf ástungu til sýnatöku til fullrar greiningar. Slíkt inngrip hefur vissa hættu á fósturláti í för með sér.

Framfarir og próun í erfðafræði hafa getið af sér nýja möguleika í pessu ferli par sem NIPT (non-invasive prenatal testing) kemur til sögunnar. NIPT er greiningarpróf par sem erfðaefni fósturs er einangrað úr blóði móður og hægt er að kortleggja litningagerð pess og par með greina frávik. Ótvíræður er kostur pess að ekki parf hættulegt inngrip til greiningar, en líta má á pað sem ókost að við getum setið uppi með óparflega miklar upplýsingar.

Notkun pessarar tækni er mislangt á veg komin í nágrannalöndum okkar og ekki komin í gagnið hér á landi. Löggjöf, faglegar vinnureglur og viðhorf til fósturgreiningar og meðferðar á meðgöngu eru mismunandi milli landa og var pað meðal umræðuefna á norrænu pingi um fósturgreiningu og meðgöngusjúkdóma sem nýlega var haldið í Reykjavík og fjallað er um í pessu tölublaði.

Pingið var pverfaglegt par sem fæðinga- og kvensjúkdómalæknar, erfðafræðingar, ljósmæður, siðfræðingar og erfðaráðgjafar tóku pátt auk leikmanna, ef leikmenn skyldi kalla; fólk sem hefur nýtt sér möguleika fósturskimunar og -greiningar og purft að taka erfiðar ákvarðanir par að lútandi. Einkum var málping um siðfræði og reynslu foreldra áhugavert og vandað og bar vitni auðmjúkum áhuga pessara sérfræðinga á siðfræðilegum álitamálum og vanda í sérgrein sinni. Siðfræðiumræðan tekur aldrei enda og á ekki að gera pað. Hún er okkur nauðsynlegur stuðningur í starfi.

\section{Heimild}

Klínískar leiðbeiningar um meðgönguvernd heilbrigðra kvenna í eðlilegri meðgöngu. Embætti landlæknis 2008 (endurskoðun 2010).

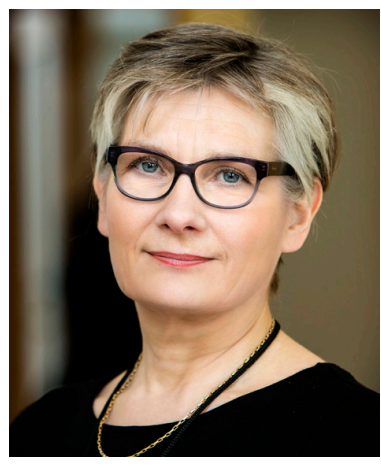

\section{Póra Steingrímsdóttir}

fæðinga- og kvensjúkdómalæknir við læknadeild Háskóla Íslands og kvennadeild Landspítala

thoraste@landspitali.is

\section{Screening in Pregnancy and Fetal Medicine}

Póra Steingrímsdóttir MD, Professor of Obstetrics and Gynecology, University of Iceland

doi.org/10.17992/lbl.2018.06.186 